\title{
Siipikarjanlihan kulutukseen vaikuttavat tekijät kotitalouksissa ja ruokapalveluissa
}

\author{
Merja Isoniemi ${ }^{1}$, Sari Forsman-Hugg ${ }^{2}$, Johanna Mäkelä ${ }^{1}$ Jaana Paananen $^{2}$ ja Eija Pouta ${ }^{2}$ \\ ${ }^{1}$ Kuluttajatutkimuskeskus, PL 5, 00531 Helsinki, etunimi.sukunimi@kuluttajatutkimuskeskus.fi \\ ${ }^{2}$ MTT Taloustutkimus, Luutnantintie 13,00410 Helsinki, etunimi.sukunimi@mtt.fi
}

Kiristyvä kansainvälinen kilpailu EU:n siipikarjanlihamarkkinoilla on asettanut suomalaisen siipikarjanlihantuotannon uusien haasteiden eteen. Suomalaisen tuotannon korkea tuotantohygienia, hyvä eläintautitilanne ja sopimustuotannon mahdollistama nopea reagointi mahdollisiin kriisitilanteisiin ovat vahvuuksia ja kilpailutekijöitä, joita voidaan hyödyntää markkinoinnissa kuluttajille. Tehokas markkinointiviestintä edellyttää kuitenkin tietoa kuluttajien käsityksistä siipikarjanlihantuotannosta sekä ymmärrystä kuluttajien siipikarjanlihan ostopäätöksiin vaikuttavista tekijöistä.

Tutkimuksessa selvitetään siipikarjanlihan käyttötapoja sekä osto- ja kulutuspäätöksiin vaikuttavia tekijöitä kotitalouksissa ja ruokapalveluyrityksissä. Tutkimuksen tavoitteena on tunnistaa suomalaisen siipikarjanlihantuotannon vahvuuksia ja kehittämiskohteita erityisesti kuluttajien näkökulmasta. Tutkimus kuuluu viiden tutkimusosion muodostamaan hankekokonaisuuteen "Suomalaisen siipikarjanlihantuotannon kilpailukyvyn ja kulutuksen edistäminen", jota rahoittavat maa- ja metsätalousministeriö, elinkeinon toimijat ja tutkimuslaitokset. Tutkimuksen tuloksia voidaan hyödyntää suomalaisen siipikarjanlihan kuluttajaviestinnässä ja toimialan laatuketjun kehittämisessä. Tutkimuksen toteuttavat yhteistyössä Kuluttajatutkimuskeskus ja MTT Taloustutkimus.

Tutkimus on toteutettu kahdessa vaiheessa keräämällä sekä laadullista että määrällistä aineistoa syksyllä 2006 ja 2007. Laadullinen aineisto koostui kuluttajien ryhmäkeskusteluista ja ruokapalveluyritysten edustajien henkilökohtaisista haastatteluista. Tutkimuksen määrällinen osio toteutettiin kuluttajille $(\mathrm{N}=1312)$ tehdyn Internet-kyselyn avulla. Tässä artikkelissa keskitytään kuluttajakyselyn tulosten tarkasteluun. Kyselyllä tuotettiin yleistettävää tietoa siipikarjanlihan kuluttajista, kulutustavoista sekä kuluttajien valintapäätöksistä vähittäiskaupassa ja ruokailtaessa kodin ulkopuolella. Lisäksi tutkittiin kuluttajien käsityksiä suomalaisesta tuotantoketjusta suhteessa kahteen esimerkkituontimaahan. Kyselyssä arvioitiin myös erilaisten tuotantotapojen vaikutusta kuluttajien ostoaikomuksiin.

Tulokset osoittavat broileriaterian olevan suosittu valinta sekä kotona että kodin ulkopuolella ruokailtaessa. Broilerituotteiden valinnassa kuluttajat pitivät keskeisinä tuotteiden turvallisuutta ja terveellisyyttä. Myös broilerinlihan alkuperä oli kuluttajille tärkeää. Valtaosa kuluttajista ilmoitti ostavansa suomalaista broileria, koska luottaa suomalaiseen ruoantuotantoon. Suomalaisen broilerinlihantuotannon vahvuuksia verrattuna tanskalaiseen ja brasilialaiseen tuotantoon olivat kuluttajien näkemyksissä lyhyt ketju, alkuperän jäljitettävyys, hallittu tautitilanne ja ketjuyhteistyö. Geenimuunnellun rehun käyttäminen broilerien ruokinnassa alensi valtaosalla kuluttajia halukkuutta valita tuote. Vain viidesosa kuluttajista koki broilerin makua parantavan ruokinnan tuovan tuotteelle lisäarvoa.

\section{Asiasanat:}

Siipikarjanlihan kulutus, kuluttajat, asenteet, alkuperä, tuotantotapa 


\section{Johdanto}

Kiristyvä kansainvälinen kilpailu EU:n siipikarjanlihamarkkinoilla on asettanut suomalaisen siipikarjanlihantuotannon uusien haasteiden eteen. Korkeiden tuotantokustannusten lisäksi Suomessa siipikarjanlihantuotantoon vaikuttaa tiukka ympäristö- ja eläinten hyvinvointilainsäädäntö. Toisaalta suomalaisen tuotannon hyvä tuotantohygienia ja eläintautitilanne sekä sopimustuotannon mahdollistama nopea reagointi mahdollisiin kriisitilanteisiin ovat vahvuuksia ja kilpailutekijöitä, joita voidaan hyödyntää kuluttajamarkkinoinnissa (Ristiluoma ja Ovaska 2005). Tehokas markkinointiviestintä edellyttää kuitenkin tietoa kuluttajien siipikarjanlihantuotantoon liittyvistä käsityksistä sekä ymmärrystä siipikarjanlihan valinta- ja ostopäätöksiin vaikuttavista tekijöistä. Beckerin (2000) mukaan kuluttajat ovat valmiita maksamaan korkeamman hinnan parempilaatuisesta tuotteesta, mikäli tieto paremmasta laadusta tavoittaa kuluttajan ostotilanteessa. Tiedon on myös oltava uskottavaa ja kuluttajalle merkityksellistä.

Siipikarjanlihan kokonaiskulutus oli ennakkotietojen mukaan vuonna 2006 hieman yli $16 \mathrm{~kg}$ henkeä kohden, josta valtaosa, yli $13 \mathrm{~kg}$, oli broileria (Suomen Gallup Elintarviketieto 2007). Siipikarjanlihan tuonti on kasvanut kaksinkertaiseksi 2000-luvulla. Tuontiliha on käytetty suurimmaksi osaksi lihanjalostusteollisuudessa ja ravintoloissa. (Välimäki 2006). Ravintoloiden ja suurkeittiöiden tarjoamien aterioiden määrä vuonna 2006 oli 781,9 miljoonaa annosta (Suomen Gallup Elintarviketieto 2007). Ravintolaruokailun trenditutkimuksen (Minkkinen 2006) mukaan joka kymmenes kodin ulkopuolella nautittu ateria sisälsi siipikarjanlihaa. Kodin ulkopuolella ruokailun lisääntyessä merkittävä osa siipikarjanlihan kulutuspäätöksistä tapahtuu ruokapalvelualalla.

Tutkimus kuuluu hankekokonaisuuteen "Suomalaisen siipikarjanlihantuotannon kilpailukyvyn ja kulutuksen edistäminen", jossa suomalaisen siipikarjanlihaketjun eri osa-alueita tarkastellaan viiden toisiaan täydentävän osion avulla. Hanketta rahoittavat maa- ja metsätalousministeriö, elinkeinon toimijat ja tutkimuslaitokset. Nyt esiteltävä tutkimus kohdistuu siipikarjanlihan kulutukseen kotitalouksissa ja ruokapalveluyrityksissä. Tässä artikkelissa raportoidaan tutkimuksen alustavia tuloksia. Tutkimuksen tavoitteena oli saada kuvailevaa ja yleistettävää tietoa siipikarjanlihan kuluttajista, kulutustavoista sekä kuluttajien valinta- ja ostopäätöksistä kotitalouksissa ja kodin ulkopuolella ruokailtaessa. Tutkimuksessa tuotettiin tietoa myös kuluttajien broilerintuotantoon liittyvistä näkemyksistä sekä asemoitiin suomalaisen broilerintuotannon vahvuuksia ja heikkouksia kuluttajien käsityksissä.

\section{Aineistot ja menetelmät}

Tutkimus toteutettiin kahdessa vaiheessa tuottamalla ja analysoimalla sekä laadullista että määrällistä aineistoa. Laadullinen aineisto kerättiin kuluttajien ryhmäkeskusteluilla ja ruokapalveluyritysten edustajien henkilökohtaisilla haastatteluilla syksyllä 2006. Kaikkiaan laadulliseen tutkimukseen osallistui 37 kuluttajaa pääkaupunkiseudulta ja 18 liharaaka-aineiden hankinnoista vastaavaa henkilöä erityyppisistä ravintoloista ja suurkeittiöistä eri puolelta Suomea. Laadullisen aineiston tuottamaa tietoa hyödynnettiin määrällisen vaiheen suunnittelussa.

Tutkimuksen määrällinen osio oli marraskuussa 2007 kuluttajille suunnattu Internet-kysely. Kyselyn teknisestä toteutuksesta ja aineiston keruusta vastasi Taloustutkimus Oy Internet-paneelinsa avulla. Kysely koostui seuraavista osioista: 1) siipikarjanlihan kulutus ja valintakriteerit, 2) näkemykset siipikarjanlihantuotannosta, 3) asennemittarit ja 4) taustatiedot. Kysely kohdistettiin siipikarjanlihassa erityisesti broilerinkulutukseen ja broilerintuotantoa koskeviin näkemyksiin.

Kyselyyn vastasi 1312 kuluttajaa (vastausprosentti 51). Kyselyyn osallistuneista naisten ja miesten osuus oli lähes samansuuruinen. Vastanneet olivat 18-79-vuotiaita, ja heidän keski-ikänsä oli 49 vuotta. Kyselyyn osallistuneet olivat suhteellisen korkeasti koulutettuja, sillä pelkästään perusasteen koulutuksen saaneita oli vain 11 prosenttia. Kaksi kolmasosaa vastanneista kuului pieneen, yhden tai kahden hengen talouteen. Lapsiperheiden osuus oli alle kolmannes talouksista. Kyselyyn vastanneista $43 \%$ asui Etelä-Suomen läänissä ja 36 \% Länsi-Suomen läänissä. Suurin osa (69 \%) asui kaupunkimaisessa ympäristössä.

Aineiston perusanalyyseissä käytettiin frekvenssejä, ristiintaulukointia sekä keskiarvoja ja tilastollisen merkitsevyyden tarkasteluun $\chi^{2}$-testiä. Suomalaisen broilerintuotannon vahvuuksia suhteessa kilpailijamaihin tutkittiin erotteluanalyysillä. 


\section{Tulokset ja tulosten tarkastelu}

\section{Terveellistä ja turvallista suomalaista siipikarjanlihaa}

Laadulliseen tutkimusosioon osallistuneet kuluttajat ja ravintoloiden sekä suurkeittiöiden edustajat luottivat suomalaiseen siipikarjanlihaan. Sitä pidettiin turvallisena ja sen tuotantoketjua lyhyenä ja helposti jäljitettävänä. Kuluttajien arjessa erityisesti broileri oli terveellinen, nopea ja helppo kotiruoan raaka-aine. Myös suurimmalle osalle ravintoloita ja suurkeittiöitä siipikarjanlihan suomalainen alkuperä oli tärkeä valintakriteeri. Sekä kuluttajat että ravintoloiden ja suurkeittiöiden edustajat toivoivat markkinoille enemmän erilaistettuja siipikarjanlihatuotteita. Ravintoloiden ja suurkeittiöiden toiveet kohdistuivat nykyistä pidemmälle jalostettuihin siipikarjanlihatuotteisiin. Kuluttajat kaipasivat markkinoille erityistä "laatubroileria", joka poikkeaisi kasvatusoloiltaan ja maultaan edukseen tavanomaisesta broilerista.

\section{Broileri suosittu valinta kotona ja kodin ulkopuolella ruokailtaessa}

Tutkimuksen määrällisessä osiossa selvitettiin kuluttajien siipikarjanlihan kulutustapoja kysymällä broilerin- ja kalkkunanliharuokien käyttöä suhteessa kala- ja kasvisruokien sekä naudanliha- ja porsaanliharuokien käyttöön kotona ja kodin ulkopuolella ruokailtaessa. Vastaajia pyydettiin myös arvioimaan lihan, kalan ja kasvisten kulutusmuutoksia omalla kohdallaan viimeisten viiden vuoden aikana.

Kyselyyn osallistuneet kuluttajat söivät kotona useimmin kasvis- ja broileriruokia. Kolmesti viikossa tai useammin kasvisruokia söi kotona $15 \%$ vastaajista ja broileriruokia $11 \%$ vastaajista. Yli puolet kyselyyn vastanneista söi kotona vähintään kerran viikossa kala-, naudanliha- ja porsaanliharuokia. Selvästi useampi (71 \%) söi vähintään kerran viikossa kotona broileriruokia. Kaikkein useimmin broileria suosivat kotiruokana naiset, lapsiperheisiin kuuluvat ja 18-60-vuotiaat kuluttajat.

Kyselyyn osallistuneet kuluttajat söivät myös kodin ulkopuolella useimmin broileriruokia, joskaan ero naudanliharuokien käyttöön ei ollut suuri. Hieman yli neljännes vastaajista (27 \%) söi kodin ulkopuolella vähintään kerran viikossa broileriruokia ja yli puolet (55 \%) vähintään kerran kuukaudessa. Naudanliharuokia söi kodin ulkopuolella vähintään kerran kuukaudessa $53 \%$ vastanneista, porsaanliharuokia $48 \%$, kalaruokia $45 \%$ ja kasvisruokia $28 \%$ vastanneista. Kaikkein useimmin broileriaterian ilmoittivat valitsevansa kodin ulkopuolella ruokaillessaan korkeasti koulutetut, työssä käyvät ja opiskelijat, lapsiperheisiin kuuluvat ja 18-60-vuotiaat kuluttajat. Kaikkein harvemmin kyselyyn osallistuneet kuluttajat söivät sekä kotona että kodin ulkopuolella kalkkunanliharuokia.

Lihan, kalan ja kasvisten kulutuksen muutosta koskeva kysymys kattoi näiden ruoka-aineiden käytön sekä kotona että kodin ulkopuolella ruokailtaessa. Noin kolmannes kyselyyn osallistuneista oli vähentänyt porsaan- ja naudanlihan käyttöä (Kuva 1).

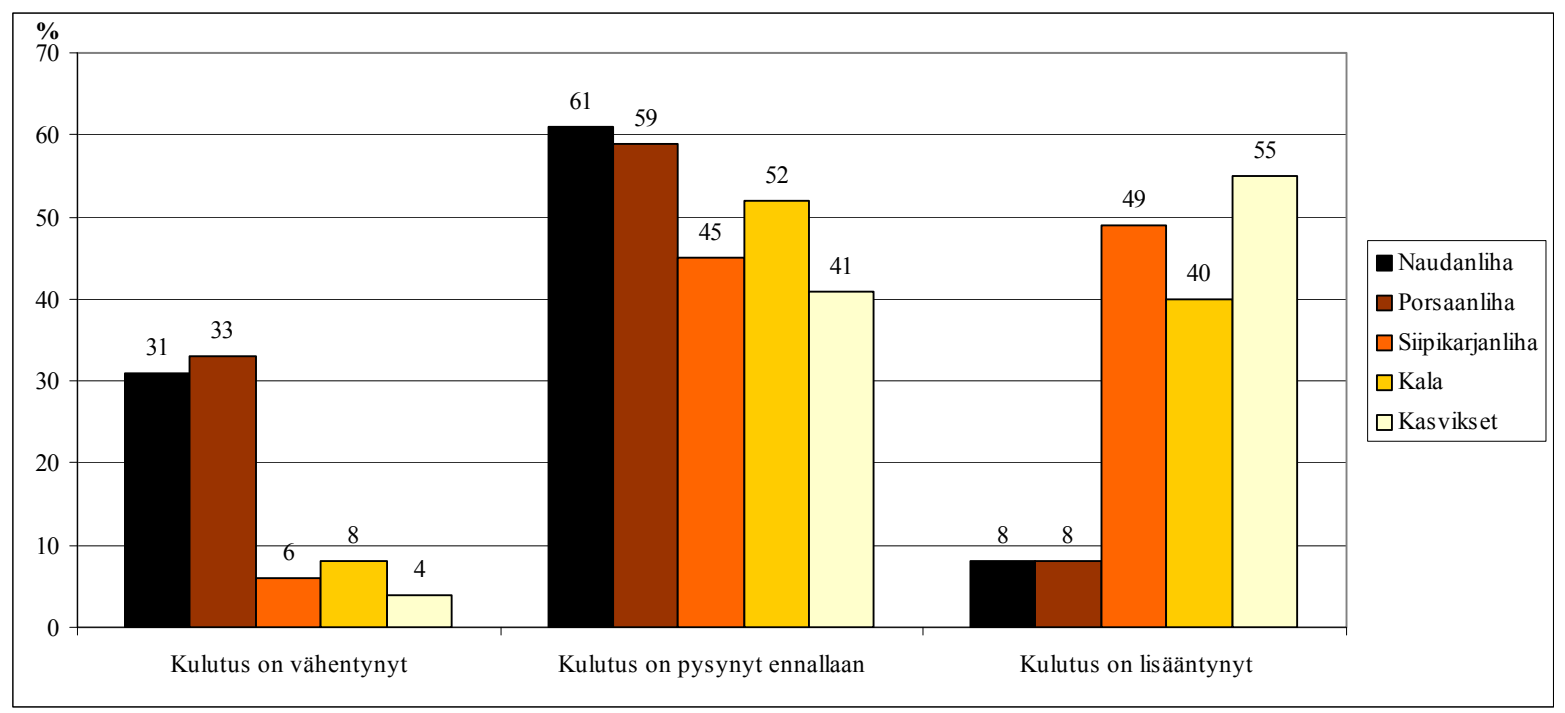

Kuva 1. Lihan, kalan ja kasvisten kulutuksen muutos kuluttajilla $(\mathrm{N}=1312)$ viimeisten viiden vuoden aikana, $\%$ vastaajista. 
Yli puolet vastaajista oli puolestaan lisännyt kasvisten ja lähes puolet siipikarjanlihan käyttöään. Monet vastaajat olivat lisänneet myös kalan käyttöä. Siipikarjanlihan kulutusta olivat lisänneet erityisesti keski-ikäiset naiset, joskaan ero eri-ikäisten naisten siipikarjanlihan kulutuksessa ei ollut tilastollisesti merkitsevä. Lihan, kalan ja kasvisten kulutusmuutokset liittynevät vastaajilla ruoan terveellisyyden merkityksen kasvuun.

\section{Turvallisuus, maku ja terveellisyys tärkeää broilerin valinnassa}

Kyselyssä selvitettiin myös broilerin valintakriteereitä. Tämä toteutettiin esittämällä vastaajille luettelo broilerituotteisiin ja broilerintuotantoon liittyvistä ominaisuuksista sekä kysymällä, miten tärkeinä vastaajat niitä pitävät ollessaan kaupassa ostamassa broilerituotteita (asteikko 1 = ei lainkaan tärkeä; 5 = erittäin tärkeä).

Kyselyyn osallistuneet pitivät kaikkia kysyttyjä asioita, sekä tuoteominaisuuksia että broilerintuotantoon liittyviä asioita, suhteellisen tärkeinä (keskiarvot asteikolla 1-5 olivat 3,49-4,68). Tärkeimpinä tuoteominaisuuksista vastaajat kokivat broilerinlihan turvallisuuden (keskiarvo 4,57), maukkauden $(4,51)$, terveellisyyden $(4,43)$ ja selkeän alkuperämaamerkinnän $(4,40)$. Broilerintuotantoon liittyvistä asioista vastaajat pitivät tärkeimpinä tuotantoketjun pientä salmonellariskiä $(4,68)$ ja lintujen terveyttä $(4,63)$ sekä sitä, että valvontaan tuotantoketjun kaikissa vaiheissa voi luottaa $(4,49)$ ja, että koko tuotantoketju tekee yhteistyötä turvallisuuden ja laadun eteen $(4,45)$. Tarkasteltaessa eri valintakriteerien merkityksellisyyttä kokonaisuutena, voidaan todeta turvallisuuden keskeinen merkitys kuluttajille siipikarjanlihaa ostettaessa. Tämä tulos välittyy tuoteominaisuuksien "turvallisuus" ja "selkeä alkuperämaamerkintä" tärkeyden kautta. Tämä käy ilmi myös siitä, miten broilerintuotantoa koskevista asioista tärkeimmiksi koetut liittyvät kuluttajille turvallisiin tuotteisiin ja toisaalta kuluttajien luottamukseen tuotantoketjun toimijoita kohtaan. Useat vastaajien tärkeinä pitämistä asioista ovat luonteeltaan sellaisia, ettei kuluttaja voi niitä kaikilta osin itse arvioida tai vaikuttaa niihin. Tämäntapaisista asioista on viestittävä kuluttajille, ja toisaalta kuluttajan on niiden osalta voitava luottaa tuotantoketjun toimijoihin ja viranomaisiin.

\section{Lyhyt ketju, alkuperän jäljitettävyys, hallittu tautitilanne ja ketjuyhteistyö suomalaisen broilerin- tuotannon vahvuuksina}

Kyselyyn osallistuneille broilerinlihan alkuperä on tärkeää; vain $11 \%$ vastaajista ilmoitti, ettei kiinnitä huomiota broilerinlihan alkuperään. Myös luottamus suomalaiseen ruoantuotantoon on vahva, sillä $89 \%$ vastanneista ilmoitti ostavansa suomalaista broilerinlihaa, koska luottaa suomalaiseen ruoantuotantoon. Toisaalta $43 \%$ vastaajista oli sitä mieltä, että suomalainen broilerinliha ei erotu tuontilihasta.

Suomalaisen broilerinlihantuotannon vahvuuksia profiloitiin kyselyssä tarkemmin vertailuasetelmalla tanskalaiseen ja brasilialaiseen broilerinlihaketjuun. Kyselyyn vastanneet arvioivat kolmen eri maan - Brasilia, Tanska, Suomi - broilerintuotantoa 17 väittämän avulla (asteikko 1 = täysin eri mieltä; 5 = täysin samaa mieltä). Mielikuvat broilerinlihan tuotantoketjusta eri maiden välillä erosivat tilastollisesti merkitsevästi lähes kaikissa väittämissä (Kuva 2). Kiinnostavaa on kuitenkin, että mielikuvat hinnasta, broilerinkasvatuksen tehotuotantomaisuudesta sekä käsitys elinkeinon kannattavuudesta tuottajalle eivät juuri eronneet alkuperämaittain. Tosin suomalainen broilerinliha miellettiin hieman kalliimmaksi tanskalaiseen ja brasilialaiseen verrattuna ja broilerinkasvatus hieman vähemmän tehotuotantomaiseksi. On kuitenkin otettava huomioon, että suurella otoskoolla pienetkin erot tulevat tilastollisesti merkitseviksi.

Mielikuvaväittämien samanaikaista erottelevuutta tarkasteltiin alustavasti erotteluanalyysillä ottamalla mukaan kaikki ne 14 muuttujaa, jotka erosivat maittain tilastollisesti merkitsevästi. Tuloksena saatiin kaksi erottelufunktiota, joista ensimmäinen (selitysosuus $94 \%$ varianssista) erotteli lähinnä suomalaisen broilerin tanskalaisesta ja brasilialaisesta broilerista. Suomalainen broileri erottui kyselyyn vastanneiden mielikuvissa erityisesti seuraavien asioiden osalta: lyhyt tuotantoketju (suurin korrelaatio muuttujan ja erottelufunktion välillä 0,85$)$, lintujen lyhyet kuljetusmatkat $(0,58)$, alkuperämaan tunnistaminen helppoa $(0,57)$, lisätiedon saaminen tuotteesta helppoa $(0,55)$, lintujen tautitilanne hallinnassa $(0,54)$, salmonellariski tuotantoketjussa pieni $(0,43)$ ja koko ketjun yhteistyö turvallisuuden ja laadun eteen $(0,39)$. 
Tämän perusteella suomalaisen broilerilihantuotannon vahvuudet kuluttajien käsityksissä voidaan tiivistää lyhyeen ketjuun, alkuperän jäljitettävyyteen, hallittuun tautitilanteeseen ja ketjuyhteistyöhön. Eettisyyden näkökulmasta kiinnostavaa on, että lintujen hyvinvointi ei noussut merkittäväksi erottelevaksi tekijäksi. Kyselyyn vastanneista $44 \%$ oli sitä mieltä, että lintujen hyvinvointiin ei kiinnitetä huomiota suomalaisessa broilerinlihaketjussa.

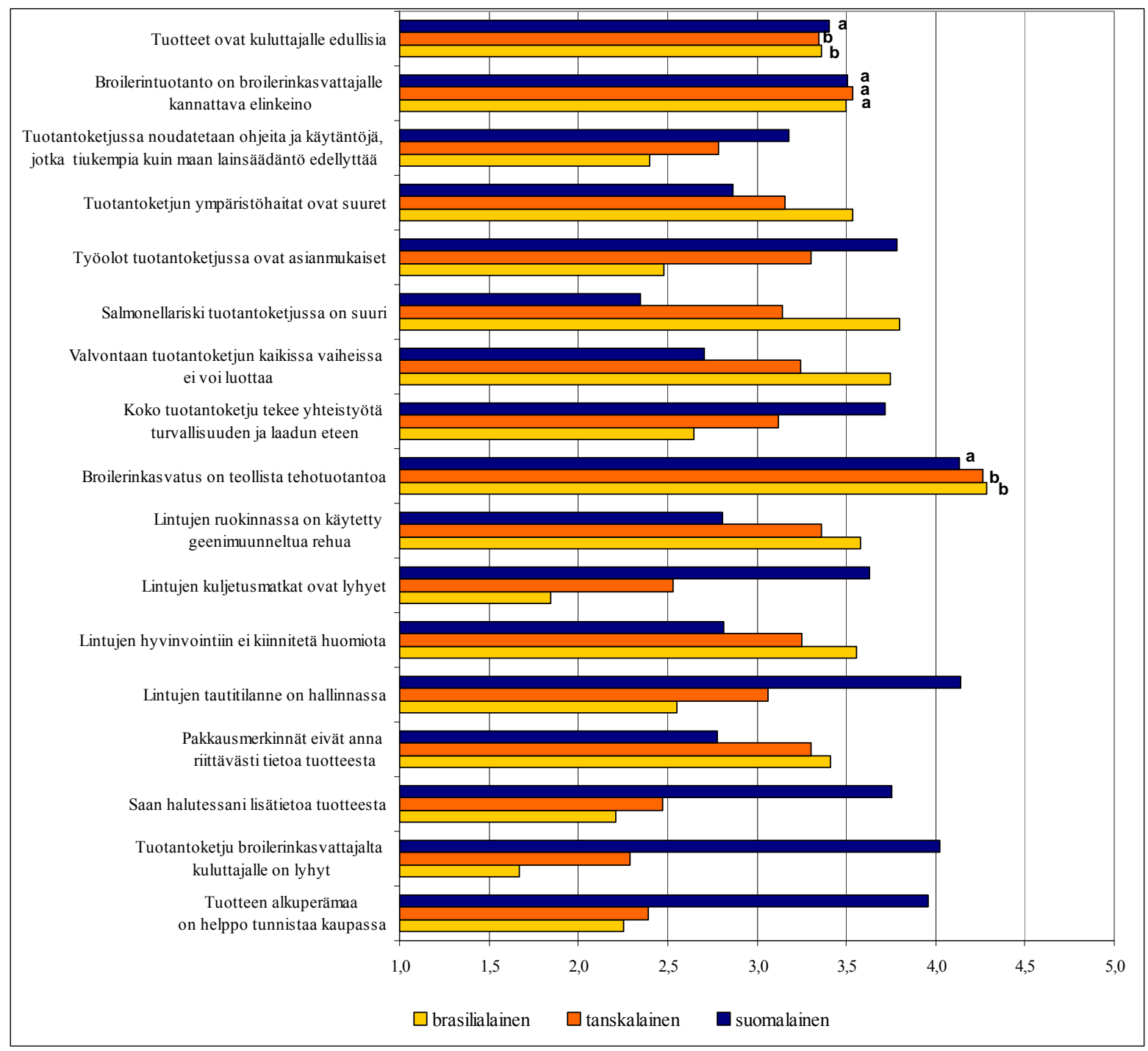

Kuva 2. Kuluttajien ( $\mathrm{N}=1$ 312) suomalaiseen, tanskalaiseen ja brasilialaiseen broilerinlihan tuotantoketjuun liittämien mielikuvien keskiarvot. Asteikko 1 = täysin eri mieltä; 5 = täysin samaa mieltä. Samalla kirjaimella merkityt alkuperämaat eivät eroa kyseisen mielikuvan suhteen tilastollisesti merkitsevyydellä 0,05 . Niissä muuttujissa, joissa ei ole kirjaimia, erot alkuperämaiden välillä ovat tilastollisesti merkitseviä. 


\section{Tuotantotapa vaikuttaa ostoaikomuksiin}

Kyselyllä selvitettiin myös kuluttajien käsityksiä geenimuunnellulla rehulla (gm-rehu) kasvatetusta broilerista. Kyselyyn osallistuneista $88 \%$ oli sitä mieltä, että gm-rehun käyttämisestä tulisi kertoa kuluttajille pakkausmerkinnöin. Vastaajia pyydettiin arvioimaan tuotevalintaansa tilanteessa, jossa gm-rehulla ruokittua broileria olisi tarjolla kaupassa. Kyselyyn vastanneista $63 \%$ jättäisi gm-rehulla kasvatetun broilerinlihan valitsematta. Noin neljäsosa valitsisi gm-rehulla ruokittua broileria, jos se olisi edullisempaa kuin tavanomainen tuote. Kyselyssä selvitettiin lisäksi gm-rehun käyttöön liittyviä uskomuksia. Yli 40 \% vastanneista oli täysin samaa mieltä siitä, että gm-rehulla tuotetun lihan vaikutuksia ihmiseen ei tunneta. Saman verran vastaajia oli täysin samaa mieltä siitä, että gm-rehun vaikutuksia eläimiin tai gm-rehun viljelyn vaikutuksia luontoon ei tunneta. Noin kolmasosa vastaajista oli vahvasti sitä mieltä, että viljelykasvien geenimuuntelu on eettisesti kyseenalaista. Gm-rehulla ruokitun broilerin jättäisivät valitsematta erityisesti naiset, keski-ikäiset kuluttajat ja maaseudulla asuvat. Jos gm-tuotanto alentaisi hintaa, siten tuotetun broilerinlihan olisivat valmiita valitsemaan keskimääräistä useammin miespuoliset, nuoret ja korkeasti koulutetut kuluttajat.

Kyselyssä vastaajia pyydettiin myös arvioimaan valintojaan, mikäli kaupassa olisi tarjolla erikoisruokinnalla kasvatetun broilerin lihaa. Kuvitteellisessa esimerkissä lihan makuun olisi vaikutettu ruokkimalla lintuja luonnonkasveilla, maissilla ja yrteillä. Noin viidesosa vastaajista oli halukas valitsemaan erikoisruokinnalla kasvatetun "herkkubroilerin" lihaa, vaikka se olisi kalliimpaa kuin tavanomainen liha. Puolet vastaajista valitsisi tuotteen, jos se olisi samanhintaista kuin tavanomainen broileri. Herkkubroilerista olivat erityisesti kiinnostuneita eteläsuomalaiset, kaupunkilaiset, ikääntyvät kuluttajat sekä kuluttajat, jotka asuivat yhden tai kahden hengen talouksissa.

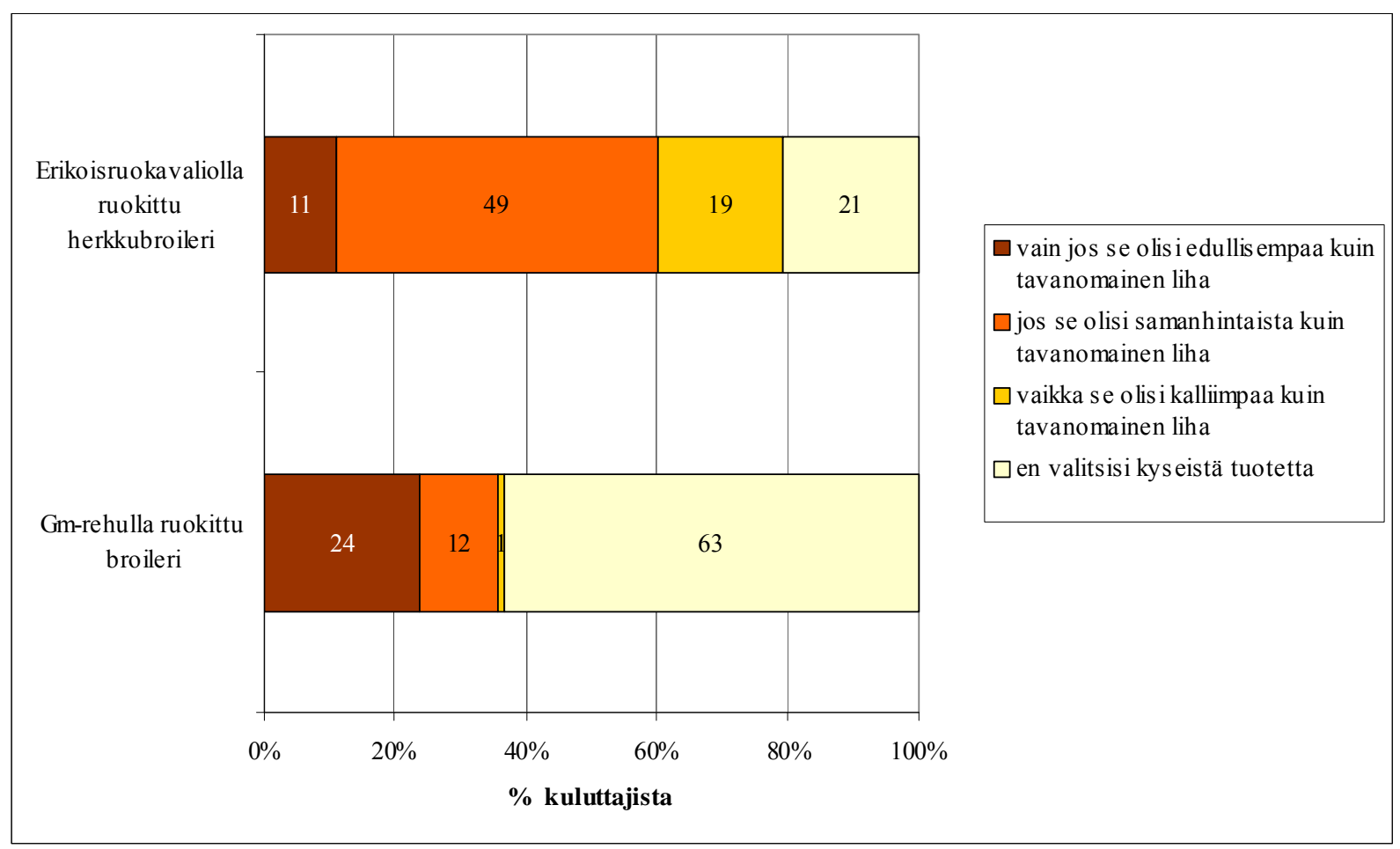

Kuva 3. Kuluttajien $(\mathrm{N}=1312)$ halukkuus valita gm-rehulla ruokittua broileria ja erikoisruokinnalla kasvatettua herkkubroileria. 


\section{Johtopäätökset}

Kuluttajat arvostavat arjessaan ruoan terveellisyyttä, hyvää makua, turvallisia elintarvikkeita sekä ruoanvalmistuksen nopeutta ja helppoutta (Varjonen 2000). Siipikarjanliha vastaa monilta ominaisuuksiltaan näitä kuluttajien arvostamia asioita. Monet tähän tutkimukseen osallistuneet kuluttajat olivat lisänneet kasvisten ja siipikarjanlihan sekä kalan kulutustaan. Näissä kulutusmuutoksissa heijastunee kuluttajien kasvava kiinnostus ruoan terveellisyydestä. Terveellisyyden ohella tutkimukseen osallistuneille kuluttajille tärkeää oli broilerinlihan alkuperä. Kuluttajilla suomalaiseen alkuperään liittyy vahvasti usko ruoan turvallisuudesta (Suomen Gallup Elintarviketieto 2007). Kuluttajat ovat myös kasvavassa määrin kiinnostuneita ruoantuotannon eettisyydestä.

Kuluttajien luottamus suomalaiseen ruoantuotantoon on vahva (Piiroinen ym. 2004). Myös tässä tutkimuksessa todettiin kuluttajien vahva luottamus suomalaiseen broilerintuotantoon. Tutkimuksen perusteella suomalaisen broilerintuotannon vahvuuksia ovat lyhyt tuotantoketju, alkuperän jäljitettävyys, hallittu lintujen tautitilanne ja toimijoiden yhteistyö tuotantoketjussa. Toisaalta haasteellisena suomalaiselle broilerintuotannolle voidaan pitää heikkoa erottuvuutta, niin suomalaisten jalostajien tuotteiden kesken kuin tuontituotteista. Erityisen haasteen suomalaiselle broilerintuotannolle ja tuotteiden jatkojalostukselle muodostaa nykyinen broilerintuotantotapa, joka ei kuluttajien näkemyksissä erotu tuotannon tehotuotantomaisuudessa esimerkiksi kilpailevista brasilialaisesta ja tanskalaisesta broilerintuotannosta. Broilerituotteiden kuluttajamarkkinointia voitaisiin kehittää tuotantotapaa erilaistamalla ja viestimällä tuotantoketjun vahvuuksista.

\section{Kirjallisuus}

Becker T. 2000. Consumer perception of fresh meat guality; a framework for analysis. British Food Journal 102:158-176.

Minkkinen P. TNS Gallup Oy. 2006. Ravintolaruokailun trenditutkimus 2006. Suomen Hotelli- ja Ravintolaliitto SHR ry.

Piiroinen, S., Mäkelä, J., Niva, M. 2004. Luottavaiset suomalaiset? Kuluttajien näkemykset ruoan turvallisuudesta. Kuluttajatutkimuskeskuksen julkaisuja 4/2004.

Ristiluoma, R., Ovaska, S. 2005. Suomalaisen siipikarjanlihan tuotannon merkitys ja kilpailukyvyn edistäminen - Esiselvitysmuistio. MTT Taloustutkimus.

Suomen Gallup Elintarviketieto Oy. 2007. Ruokatieto 2007.

Varjonen J. 2000. Trendejä vai kaaosta? Ruokatottumusten ja ruokataloudenhoidon muutokset 1980- ja 1990luvuilla. Kuluttajatutkimuskeskuksen julkaisuja 2/2000.

Välimäki K. 2006. Teurastus- ja lihanjalostusteollisuus. Toimialaraportti 4/2006. KTM:n ja TE-keskusten julkaisu. 